\title{
The Polymorphy of Cutleria multifida (Grev.).
}

BY

\author{
ARTHUR H. CHURCH, B.A., B.SC., \\ Jesus College, Oxford: Demonstrator of Botany in the University.
}

\section{With Plates VII, VIII, and IX.}

SINCE the classical researches of Falkenberg ${ }^{1}$, carried out $S$ at Naples in 1878 , in which he showed the necessity of fertilization for the oospheres of Cutleria multifida (Grev.), and established the identity of the product of germination of such sexually-produced spores with Aglaozonia reptans (Kutz.), but little has been done to clear up the mystery underlying his conclusion that Cutleria must therefore present an antithetic alternation of generations, in which Cutleria multifida represents the gametophyte, while Aglaozonia reptans is to be regarded as a true sporophyte-generation.

Conclusive evidence of such an alternation of generations would be of greatest theoretical interest; not so much from its being the only example described in the Phaeophyceae of an antithetic alternation at all comparable with the phenomena occurring in the Coleochaetaceae and the Florideae,

${ }^{1}$ Die Befruchtung und der Generationswechsel von Cutleria: Mittheilungen aus der Zoolog. Stat. zu Neapel, vol. i. I879.

[Annals of Botany, Vo1. XII. No. XL.V. March, I898.] 
which are regarded as possibly representing evolutions of alternation, in existing groups of Green and Red Algae, parallel to that which has reached such a degree of complexity in the Archegoniatae; as from its presenting, within the limits of a very narrow alliance, a sudden transition to a true alternation from the simpler life-history of the homotype genus Zanardinia.

Falkenberg showed, beyond all doubt, that Aglaozonia plants were normally the ultimate product of sexual reproduction in Cutleria multifida; but, owing to the death of his plants, the question as to the subsequent relations of the Aglaozonia to Cutlevia-whether the latter arose from spores, or was the result of merely vegetative reproductive processes-was left open; as was also that of the strictness of the alternation on the side of the perennial and more widely distributed Aglaozonia.

Although the following observations, made at the Marine Biological Laboratory at Plymouth, cannot be regarded as finally solving the problem, it is hoped that they may contribute to a more complete acquaintance with the life-history of these plants.

Both Cutleria and Aglaozonia grow in the estuary of the river Yealm, near Plymouth, at 2-3 fathoms below low-water mark, and may easily be obtained, at all states of the tide, by dredging. Cutleria grows as a summer annual, reaching its maximum development in July and the beginning of August. It rapidly diminishes in quantity in September, and has completely disappeared by October. Aglaozonia, on the other hand, is perennial, growing on stones and shells, especially oyster-shells, in the same locality and depth, reaching its finest development in October and November. Poor in quality during the winter-months, possibly owing to its being eaten by Mollusca \&c. in the absence of other vegetation, it recovers in the spring, and bears reproductive sori in March and April. It is also usually in poor condition throughout the summer. From these data, it would appear, therefore, that in English waters Cutleria is a rapidly- 
developing summer sexual plant, Aglaozonia a slow-growing perennating winter form; and that these two growth-forms had become complementary in structure and habit, as well as in reproductive functions.

A consideration of the conditions under which these two plants live in the Bay of Naples shows, however, that this does not represent the whole truth. The majority of the most interesting of the summer annuals growing in shallow water on the southern shores of England are, in the Bay of Naples, early spring- and even winter-plants; while others, on the other hand, retire to deeper water. A few examples will make this clear: thus, Cutleria at Plymouth grows in company with abundant Sporochmus, Arthrocladia, Stilophora, Asperococcus bullosus, Dictyota, and such Florideae as Dudresnaya coccinea and Scinaia furcellata; all these forms reproducing freely in July and the beginning of August, and growing in 2-3 fathoms of water at a temperature of $18^{\circ} \mathrm{C}$. From data given by Falkenberg for the Bay of Naples, it appears that Sporochnus and Arthrocladia flourish also there in July and August, but at a depth of 20 fathoms; Stilophora follows the Cystoseira zone at a slightly less depth and grows in early summer; Asperococcus bullosus also in spring and summer, varying from I-8 fathoms; Dudresnaya at 2 fathoms in March and May; and Scinaia at the same depth from February to June, although the latter has been dredged at Messina in July at 15 fathoms.

Of the plants with which Cutleria grows in English waters, therefore, some retain at Naples the same annual period, but live in far deeper water; but more generally the depth of water remains fairly constant, while the season of the year is changed. There can be little doubt that the two determining factors of external environment are temperature and intensity of sunlight, with the latter being associated a greater degree of purity in the water, which in the Bay of Naples allows vegetation to flourish as far out as 40 fathoms, while, in the immediate vicinity of Plymouth Sound, only scanty traces are met with at even 10 fathoms. Cutleria 
at Naples follows the rule of the majority of its English associates and vegetates in shallow water from December to April, vanishing, like Dictyota in the Mediterranean, on the approach of summer. It is important to note that while Aglaozonia is also perennial in the Bay of Naples, Cutleria is the winter-form, completely disappearing by April, its existence being apparently terminated by a rise of temperature, instead of by a fall as on the English coasts. It is clear, therefore, that the vital capacities of the sexual plant towards temperature are much more limited than those of the asexual Aglaozonia, which is perennial, not only in the warmer waters of the Mediterranean summer, but in the cold waters of the North Atlantic and North Sea winter.

If now we compare the geographical distribution of the known species of the Cutleriaceae ${ }^{1}$, we find that the order belongs naturally to the warmer seas. Thus, omitting the doubtful C. Laminaria, Kutz. of the Mediterranean, the group consists of two little known species, C. pacifica from Samoa, and $C$. compressa from La Guayra; of $C$. adspersa of the Mediterranean district only ${ }^{2}$ (Cadiz to Suez); of Zanardinia collaris, Mediterranean, West Indies, Polynesia, the Atlantic shores of Europe as far as Brest (Crouan), drifted specimens at Jersey (Harvey); and of $C$. multifida, also a Mediterranean and Atlantic type ${ }^{3}$. But this last, alone of the group, extends northwards to England, Shetland Islands, and the coast of Norway to Nordland (Kjellman); on the other hand, it is poorly represented in the North Sea district and absent in the Baltic. That is to say, the northward distribution of the sexual form appears to be limited

\footnotetext{
1 De Toni, Sylloge Algarum, vol. iii. p. 300.

${ }^{2}$ Sauvageau (Journ. de Bot. I897, p. I 77 ) since gives C. adspersa and an undetermined Aglazonia, but neither $C$. multifida nor Zanardinia, as being abundant in winter, at low-tide mark, in the Gulf of Gascony; and Mr. Batters informs me that $C$. adspersa is found at Brest.

${ }^{3}$ A doubtful Polynesian form of Aglaozonia described as Zonaria parvula var. duplex (Heydr. Beitr. Algenfl. v. Kais. Wilh. Land), placed by De Toni under C. multifida, might more possibly belong to $C$. pacifica.
} 
by the temperature of the northern summer, and in the English Channel we are already beyond the natural home of the Cutleria family.

\section{PARTHENOGENESis OF CUTLERta.}

The first recorded specimen of $C$. multifida was picked up after a storm on Yarmouth beach by Dawson Turner on August $3{ }^{\mathrm{I}}, \mathbf{1 8 0 4}^{1}$. It was a female plant, covered with oogonia as the date would suggest, and was described in Smith and Sowerby's English Botany in I 805 , under the name of Ulva multifida (No. I913). It appears as Zonaria multifida in Agardh's Sp. Alg. 1824, and as Sporochmus multifidus in Sprengel's Systema Vegetabilium of Linnaeus, in 182.5 ; it received its modern title in 1830 , from Greville ${ }^{2}$, who formed for it a new genus, named in honour of Miss Cutler of Sidmouth. Greville, also, knew only the female, or as it was considered, the sporangiate plant. Antheridial plants were described later by Dickie, but these were very rare, and Harvey in his Phycologia Britannica (1 846) mentions that he had never seen more than one such plant, which had been sent him from Sidmouth.

At this time no sexual significance had been attributed to the reproductive cells of Algae, or these antheridia might have been a source of difficulty; but they were commonly regarded as imperfectly formed swarming cells which were consequently destined to remain sterile ${ }^{3}$. The first definite statements with regard to the emission and germination of the spores were made by Thuret ${ }^{4}$ in $185^{\circ}$. He observed the discharge of the oospheres in the early hours of the morning, as also their active movement and strong positive heliotropism by means of which they rose to the surface of the water. In all cases germination was direct; the

1 Harvey, Phycologia Britannica, i. 33.

2 Algae Britannicae, p. 60.

${ }^{3}$ Cp. Nägeli, Bot. Zeit. I849, p. 569 .

+ Ann. Sci. Nat. iii. I4, p. $3^{2}$. 
oospheres came to rest, the pointed end grew out to form a rhizoid, the body of the spore giving a brown filament of a few cells. A number of female plants, kept in a vessel of sea-water, continued to give off oospheres for several successive days, which in all cases germinated perfectly without the admission of antherozoids. Thus, although Thuret was fully satisfied as to the necessity of antherozoids for the fertilization of the oospheres of Fucus, he concluded that no act of fertilization took place in the Cutleria spores he had under observation. It is also of special interest to note that he found antheridial specimens to be extremely rare at Saint Vaast-la-Hogue, where these researches were conducted; he states that he often collected from the oyster-beds there, where Cutleria grew in profusion, over a hundred female specimens before finding one male; and he points out that this rarity of antheridial specimens not only agrees with what Harvey had stated to be the case in English waters, but would to a certain extent militate against the view that antherozoids possessed sexual functions of such importance to the plant.

In the summer of 1855 , the brothers Crouan ${ }^{1}$ repeated these observations at Brest, and came to identical conclusions with regard to the perfect parthenogenesis of the oospheres. At the same time, they noted a peculiar phenomenon in connexion with the fate of the antherozoids. These at first rose to the surface of the water, forming an orange film on the side nearest the light, in the manner typical for all swarming cells of the Brown Seaweeds; but on coming to rest, they became agglutinated by their gelatinous membranes into a pseudo-tissue mass of a brown colour, which was even capable of being sectioned. They therefore concluded that the antherozoids were non-sexual, but still possessed a certain degree of germinative capacity. It is so far clear that to the older observers who worked on the French shores of the Channel, the constancy of the germination of the oospheres

${ }^{1}$ Bull. Soc. Bot. France, ii. p. 644 . 
was so apparent that the question of the non-sexuality of Cutleria was never in doubt.

The converse was however asserted by Reinke ${ }^{1}$ in carrying out his researches at the Naples Station in I875-76. He confirmed Crouan's observations on the peculiar pseudo-tissue formation of the antherozoids, but attributed to it no real germinative significance, since in all his experiments, antherozoids and oospheres, isolated from each other, constantly underwent no further development. On the other hand, in vessels containing both male and female plants, germination took place freely, and actual fertilization by the antherozoids was observed. From these facts he deduced the perfect sexuality of $C$. multifida and the essential importance of the antherozoids; as also that Thuret's observations must have been due to an accidental parthenogensis. It is interesting to note that he gives male and female plants as occurring in the Bay of Naples in the ratio of three male to two female.

Similarly Falkenberg ${ }^{2}$, in 1878 , described male and female plants as being about equally abundant in the Bay of Naples, and carrying out his experiments with great care in obtaining pure cultures of emitted oospheres and antherozoids, he fully confirmed Reinke's results. Moreover, as his cultures were free from extraneous growths of Diatoms, \&c., which had ultimately induced pathological conditions in Reinke's cultures, Falkenberg succeeded in developing the germinated embryos to a considerable size. In all his experiments, antherozoids became immotile and useless in twenty-four hours, and then died; oospheres retained the capacity for fertilization for four or five days, but never commenced segmentation; fertilized oospheres germinated directly and rapidly; while unfertilized oospheres never got beyond the formation of a thin cell-membrane.

Further, Janczewski ${ }^{3}$, at Antibes in 1883 , showed in the case of $C$. adspersa, which is also a Mediterranean spring-plant,

1 Nova Acta der K. L. C. Deutsch. Akad. xl. 1878. 2 Loc. cit.

3 Ann. Sci. Nat. vi. I6. p. 2 Io. 
that neither male nor female sexual cells present any of these curious suggestions of direct development, but that both oospheres and antherozoids die the same day if copulation does not take place.

During the summer of 1896 , male plants were extremely rare at Plymouth, only two or three being seen, although female plants were dredged in considerable quantity. In I 897 the same proportion obtained: thus, in a dredging taken on August II, a score or so of very fine female plants were collected, but only one male. Some of these were placed in a vessel of filtered water with the object of obtaining embryos, but owing to the heat or some other cause, the plants all died; nor was it until the end of the month, when cold and wet weather set in, that freshly dredged material could be kept alive more than a day or two. At this time and onwards, all the plants obtained were female, no more male plants being seen for the year. With the object of testing Thuret's observations on direct germination, a number of female plants were on August 20 placed in filtered water (temp. $18^{\circ} \mathrm{C}$.) standing in a north window. In the course of three weeks, the water having only once been changed, the fronds were found to be sprinkled all over with innumerable young plants, which by September I 6 presented unmistakable Aglaozonia characters (Figs. I4-2I). Although the immediate proximity of such numbers of these young plants to the sori of oogonia suggested at once the direct germination of oospheres which had lost their motility soon after discharge, it was quite possible that fertilization might have taken place before collection. More plants were accordingly collected in September, and washed and placed in filtered water. In a week the surface of the vessel was covered with thousands of germinating oospheres which had risen to the surface in virtue of their strong positive heliotropism; of these, the majority at least must have been parthenogenetic, as it is evident that any few antherozoids, which might have survived collection and washing on the female plants, would not have sufficed for such a multitude of oospheres. 
On adding a fresh supply of filtered water, another week gave a second similar crop of germinating oospheres, and a third week yet another, thus confirming Thuret's original observations.

Several distinct cultures, some containing fragments of female thallus, still producing oospheres, which had been growing in filtered water in the laboratory since August, others containing freshly discharged oospheres only, were made towards the end of September. In all cases germination proceeded directly and quite normally, although slower than in the case of the first crop obtained in August, and far slower than in the experiments of Falkenberg, who states that his fertilized oospheres produced a plant of $3^{-4}$ cells in the first twenty-four hours, whereas the Plymouth cultures in September did not do more than this in the first week. It is probable, however, that this rate of growth varies directly with the temperature.

Finally, separate cultures, from small pieces of female plants collected on September 2I, were made on October I2, and brought to Oxford and kept in a sunny window. In all cases germination again took place normally; in three days sufficient oospheres had collected on the side nearest the light to form a visible film. The majority of the oospheres were covered with a well-marked membrane and many had already put out the first rhizoid. The temperature was low $\left(14^{\circ}\right)$ and the weather dull, but after two days of bright sunshine the plants increased to about five cells and a long rhizoid, and by October 25 they formed well-grown embryos in which segmentation was rapidly proceeding (Fig. I3).

At the end of three weeks (November I), the culturevessels having latterly been standing in bright sun for a few hours every day, an immense number of young plants in all stages of development were to be seen, the small piece of thallus in the culture continuing to give off oospheres. The oldest plants showed the 'foot-embryo' now at its maximum size, but with so far no formation of dorsiventral lobes (Fig. I4). That is to say, the germination of these unmistakably 
parthenogenetic spores had proceeded at a rate equal to and with results in a given time identical with those observed in the first culture of August II, and in which the possibility had not been eliminated that fertilized oospheres might have already become attached to the plants before they were gathered. That oospheres did this in the natural state was observed on specimens dredged in September, but it is clear that continued crops of free-swimming oospheres, germinating at the surface, were beyond suspicion. It is also of interest to note that the old plants which continued to give these crops of germinating oospheres had been, since the middle of September, in a rapid state of disintegration, and by November I were but partial skeletons compared with the perfect summer-plants; nor, at this time, would they have been found by dredging. No Cutleria was dredged at Plymouth in 1896-97 after the middle of September, the plants then evidently decaying and easily losing their point of attachment.

The general result of these observations, therefore, is not only to confirm the original observations of Thuret and Crouan, made on the opposite shores of the Channel, as to the absolute constancy of parthenogenetic development of the oospheres at the end of the summer; but, bearing in mind the equal constancy of fertilization observed by Reinke and Falkenberg in early spring at Naples, it further leads us to correlate the apparent contradiction of these observations with the fact that the conditions of external environment are so widely different in the case of plants growing in the Channel and in the Bay of Naples respectively; and further to suggest that the parthenogenesis of the Channel plants may be due to the fall of the temperature of the sea at the end of the northern summer, which, by diminishing the sexuality of the oospheres, causes the plant to become an asexual form by degeneracy, although morphologically retaining the distinction of sex. 


\section{Germination of the OOSPHeres.}

In all cases, whether in later undoubtedly parthenogenetic cultures or in the earlier ones only doubtfully so, germination proceeded along lines absolutely identical with those described by Falkenberg for the sexually-produced spore.

The spore secretes a cell-membrane, becomes pear-shaped, and divides into a shoot-cell and a first rhizoid (Fig. I I); the latter elongates and reaches a considerable size if germination takes place at the surface of the water, but remains short on contact with any foreign body. The shoot-portion of the plant gives rise to a filament of a few cells only $(6-10)$ by intercalary rather than apical segmentation (Fig. 12), and then definitely ceases to elongate; this being, according both to Falkenberg's and the Plymouth experiments, all that remains in this type of germination to mark the primitive filamentous condition of the Cutleria (Fig. I2, one week old).

Irregular segmentation commences immediately throughout the young plant; any and ultimately every cell dividing repeatedly by walls in different quadrant-planes, until the embryo becomes a more or less club-shaped multicellular mass of tissue, attached by one extremity and still exhibiting radial symmetry (Figs. I2, I3, I4).

To this stage Falkenberg has given the name of the 'Foot,' and it is probably representative, both phylogenetically and ontogenetically, of a primitive thalloid condition in which the main axis of the plant was radially symmetrical and segmented behind the growing region in the regular manner seen in such a form as Stypocaulon. When well-developed, the foot may form a well-marked tissue-mass (Fig. I4); but it is often, and this was more general in some cultures than others, to a great extent abbreviated in development, ultimately giving rise to an embryo which was practically dorsiventral throughout (Fig. I6), and identical with the oldest embryos obtained by Janczewski ${ }^{1}$ in $C$. adspersa. 
At one or more points in the 'Foot,' any single superficial cell may initiate a new growth (Fig. I5), which, by successive $\mathrm{T}$-shaped walls, gives a lobed outgrowth which exhibits dorsiventral symmetry, and by laying down the marginal segment-walls preferentially in a radial vertical plane, assumes a fan-shaped outline, the commencement of an Aglaozonia disc (Figs. I 5, 19, 20). The formation of these lobes appears to be mainly due to the stimulus of contact, and thus a majority form discs at the point of attachment (Figs. 19, 22); but if the apex of the 'Foot' bends over, a symmetrical outgrowth may take place there, either alone or in addition to another at the base (Figs. 17, 18, 20). In the case of the foot lying more or less prostrate, several (6-8) distinct lobes may be produced, which develop rhizoids on the side towards the substratum (Figs. 20, 2I). In plants which have become detached, the dorsiventral lobes continue to be formed and exhibit a tendency to curl up, indicating a return to radial symmetry comparable to that of the proliferating 'cups' of Zanardinia.

Although many distinct cultures were made, and hundreds of embryos observed, in no single case was any further development noticed in the 'Foot'; the dorsiventral lobes slowly but steadily increasing along definite Aglaozonia lines.

Following Falkenberg, this type of plant may suitably be distinguished as the Foot-Embryo.

It will therefore be noted not only that these observations on the development of the Aglaozonia-thallus from oospheres of Cutleria absolutely confirm those of Falkenberg, but that such confirmation was necessary, since the embryos observed by Thuret $^{1}$ at Saint Vaast-la-Hogue in $185^{\circ}$ were unmistakably different: it was in fact the figure given by Thuret of a free-growing filament of thirty-six cells with branches towards the base, which appeared, as being a vegetative growth homologous with an adventitious branch, to confirm his assertion of the non-sexuality of the oospheres.

${ }^{1}$ Études Phycologiques, and Ann. Sci. Nat. iii. I4. 
Not only were the Plymouth plants truly parthenogenetic, as opposed to Falkenberg's truly fertilized ones, but they were grown in the autumn months, whereas Falkenberg's were grown in the spring; the only factor in common therefore appears to be this, that in either case the spores were obtained from mature plants about to die, from summerheat in the latter case, but from winter-cold in the former.

\section{Germination of Zoospores of Aglaozonia.}

Aglaozonia plants were first described by Greville ${ }^{1}$ in $\mathrm{I} 828$, from specimens found, appropriately enough, by Miss Cutler at Sidmouth, growing at low-tide mark on exposed sandstone rocks; these sterile plants being placed as a new species in the genus Zonaria of C. Agardh under the name Zonaria parvula. Later Greville ${ }^{2}$ founded a new genus, and changed the name to Padina parvula; and in 1833 similar sterile plants found by Crouan ${ }^{3}$ at Brest were distinguished as Padina reptans. Reproductive organs were first found on Skagerack specimens by Areschoug in 1843 and the genus refounded as Padinella. Areschoug's plants were very small, and possibly dead before examination, as his figures ${ }^{4}$ are quite misleading ${ }^{5}$.

The genus Aglaozonia was ultimately established by

1 Crypt. Flora, t. 360 .

3 Florule du Finisterre, p. I69.

5 Areschoug obtained his plants on oyster-shells at Koster, and was satisfied that they were identical with Sidmouth specimens described by Greville. His drawing appears to have been made from a squeezed-out sorus, rather than from a section; and the appearance which it presented induced Reinke to revive the old name of Zonaria parvula for a plant he obtained at Naples in I875 (Nova Acta, xl, No. I. p. 34), which was of distinctly Dictyotacean nature. Reinke's plant differs fundamentally from Aglaozonia in the structure of the thallus, the well-marked ' tetraspore,' and, above all, in the embryology, which is again that of the Dictyotaceae. It is quite obvious that Greville's Sidmouth plants were Aglaozonia, as they still grow there abundantly, and Areschoug had received specimens from that locality; but it is not clear why Reinke's distinctly Dictyotoid plants should be classed as Cutleriacean by De Toni (Sylloge Algarum, Fucoideae, p. 234). 
Zanardini ${ }^{1}$, and Kützing, in his Species Algarum (1 849), gives both Aglaozonia parvula for the English and Mediterranean plants, and Aglaozonia reptans for Crouan's specimens. The sporangia and the emission and asexuality of the zoospores were correctly described by the brothers Crouan ${ }^{2}$, at Brest, in 1856 , from the large quantities of material they found thrown up by a storm on April 5 of that year, while the first correct drawings were given by Zanardini ${ }^{3}$ in 1860 . Since then the plants have been known as Aglaozonia reptans, it being clear that Crouan's specimens were not only identical with those found elsewhere, but were the first on which the reproductive organs were definitely observed.

The discs of Aglaozonia are perennial, and are distributed from the Mediterranean along the Atlantic shores of Western Europe to the coast of Norway, being much more abundant and more widely distributed than is Cutleria along the Norwegian coast ${ }^{4}$. Again, they are more general than Cutleria in the North Sea, and are found abundantly in the more northern portion (Berwick) where Cutleria is unknown; and finally, they penetrate into the milder climate at the entrance of the Baltic, and are moderately common in the Skagerack ${ }^{5}$, where Cutleria is very rare, or only found as very young specimens. Aglaozonia reproduces in the Mediterranean in late autumn, in the Channel in early spring, and it would appear that Areschoug found his Swedish specimens in reproduction during the summer months. On March 29, I897, shells bearing fine plants of Aglaozonia with reproductive sori were dredged in the river Yealm, Plymouth. One or two sori were carefully removed, placed in a glass dish of filtered water, and allowed to stand in a window exposed to a north light. Zoospores were set free in great numbers, and rising to the surface, swam towards the side nearest the light, forming in a day or two

${ }^{1}$ Saggio di classificazione nat. delle Ficee, 1843 .

\footnotetext{
2 Bull. Soc. Bot. de France, I 857 .

3 Icon. Phycolog. Adriatica.

${ }^{4}$ Kjellmann, Handbok Skand. Hafsalgflora, I89o, p. I 7 .

${ }^{5}$ Gran, Algenvegetationen i Tonsbergfjorden.
} 
a distinct brown film. Germination, as already described by the brothers Crouan, took place immediately, and with considerable rapidity (Fig. I). As in the case of the oospheres of Cutleria, the zoospores came to rest, the anterior end became attached to the sides of the vessel or to another plant, and grew out into the first rhizoid. In the case of free-floating spores the rhizoid elongated considerably if it did not come into contact with anything, but ceased to elongate further on contact (Fig. 2). A simple filament of $3^{-6}$ cells was formed in a few days, and this agrees with the rate of germination observed for the oospheres of Cutleria grown at an approximately equal temperature.

As growth proceeded, the film stretched over the surface of the water in the vessel, forming a pure culture of germinating spores, from which portions could be readily transferred to other vessels of water similarly filtered by a Berkefeldt filter. Beyond keeping the vessels covered, to prevent evaporation and the entry of dust, no further change was made; the best results, in fact, being obtained from the original culture in which the water remained unchanged for over a month.

The filaments continued to elongate, by intercalary rather than apical growth, but the characteristic cessation of growth observed in the foot-embryo of Cutleria did not set in; steady intercalary growth enabling the filaments to double their length each week (Figs. 5, 6).

In the second or third week, differentiation in the cells of the filament became marked. The cells in the basal region of the plant increased in bulk and commenced segmenting irregularly by walls in different planes, thus rendering a lower region of the embryo multicellular by the same quadrantwalls, and at about the same age, as in the segmentation of the foot-embryo (Figs. 5-9).

This basal multicellular region is therefore homologous with the foot itself, but the embryo differs in that the filamentous terminal portion goes on growing by a definite intercalary zone (Figs. 7-10). 
A further exaggeration of the basal segmentation resulted in the formation of a small irregular attachment disc (Fig. IO); but the latter exhibited no immediate tendency to extend into dorsiventral lobes, the main energy of growth being, in this embryo, clearly localized in the filamentous portion. This continued to grow, throwing out branches above and rhizoid attachment-hairs below. In the case of plants growing on the sides of the vessel, the filaments showed a tendency to attach again at any point in their length, sending out rhizoids, and initiating a new intercalary zone of growth above each such attachment: but it is possible that this may be an abnormal result of cultivation, as the same tendency can be observed in cultures of old Cutleria plants, where the reproductive filaments elongate and attach themselves to the sides of the vessel by rhizoids and bear gametangia at irregular intervals; the filamentous portions of the adult Cutleria are, in fact, still in the condition of these filamentous embryos.

It will be seen that even these young plants present the majority of the essential characters of the Cutleria-thallus : there is, for example, the same intercalary growth of a filamentous apex, with irregular segmentation behind the growing-point leading to a multicellular condition, and the same throwing-out of branches of similar growth and of attachment-rhizoids to supplement the primitive holdfast. The only point lacking is the aggregation and fusion of the branches behind the growing-points to the peculiar fasciated thallus of the adult Cutleria.

At the beginning of May, a culture of these young plants, now a month old and forming tufts of actively assimilating filaments, was taken to Oxford and kept under observation in a shaded situation in a south window of the Botanical Laboratory. The plants continued to live and assimilate vigorously, forming a bright brown woolly growth of Ectocarpus-like filaments in the unchanged water, and maintaining their position at the surface in virtue of the gas-bubbles evolved. In still water, this phenomenon affords the surest 
test of the health of a culture, death rapidly ensuing if the plants once sink and are unable to again raise themselves. In no case was any further advance made in the formation of the adult Cutleria-thallus; the filaments in some cases showed the rope-like aggregation characteristic of the main branches of many Ectocarpus-forms, but no fusions to a pseudo-tissue took place. The filamentous mass increased in bulk for over a month, but after that the plants began to be sickly, and by the end of June the whole culture was undoubtedly so, and portions of it commenced to die off. Before dying however, in July, the plants produced multilocular reproductive organs in great abundance throughout the culture, which, on maturity, proved to be unmistakable antheridia of Cutleria (Fig. 3).

In the same culture (the only one which reached this stage, for all the plants left at Plymouth died at an early date) many of the young plants had, in addition, thrown out Aglaozonia-lobes from their attachment discs, and some of these fully equalled in extent a two months' ald Aglaozonia grown from Cutleria-oospheres (Fig. 4).

Although abnormal conditions may have led to pathological results, it was undoubtedly shown that Aglaozoniazoospores, under certain conditions, not only give rise to a Protonematoid stage of Cutleria, which on impoverishment and exposure in a sunny window in summer became precociously antheridial, but that they may, on the other hand, produce the Aglaozonia-form again, and thus the antithetic character of the alternation would fail to be established.

As already indicated, these observations are still incomplete, since the observation of the development of the mature assimilating thallus of Cutleria has yet to be made; but this is not absolutely essential, since a filamentous plant bearing oogonia, but presenting even fewer of the vegetative characters of a Cutleria, in that it was almost a constantly uniseriate filament throughout, has already been described by Kuckuck under the name $C$. multifida var. confervoides ${ }^{1}$.

\footnotetext{
${ }^{1}$ Wissenschaftliche Meeresuntersuchungen, Biolog. Anst. Helgoland, I894, i. p. 25 I.
} 
Kuckuck's plants came up spontaneously in the tanks of the Heligoland Laboratory in the summer of 1893 , and grew as short filaments attached to stones which had been collected in the North Haven in fairly shallow water ( $\mathrm{I}-3$ fathoms). Similar plants were found in reproduction in July, forming brown Elachista-like tufts on Plocamium, and sterile plants also as late as December.

Normal Cutleria is said to have been gathered at Heligoland by Wollny, but has not been known to occur there since; and although Kuckuck appears to infer that his plants reproduced their like, it is quite probable that they had all sprung from Aglaozonia-spores, and owed their late and feeble development to the cold spring and early summer of the North Sea; and that thus unfavourable conditions had led to a vegetative degeneration similar to that observed in the Plymouth cultures.

But if they had been reproduced from oospheres similar to those they bore, the confirmation of the development of a protonematoid embryo from a Cutleria-form would be of still greater theoretical interest, as confirming Thuret's original observation, and thereby assisting in the demolition of the theory of inherent necessity of an alternation of growthforms.

\section{SEASONAL DIMORPHISM.}

From the preceding considerations it is obvious that the polymorphy of Cutleria presents little in common with the antithetic alternation of primitive gametophyte and nursed sporophyte of the Archegoniatae; and still less with the case of Coleochaete and the Florideae, in which the origin of what in these forms is generally regarded as a sporophyte may be sought in polyembryony.

From the homology of the Aglaozonia-thallus with other asexual Algae such as Battersia or even Laminaria, Aglaozonia has as much claim to be regarded as theoretically a gametophyte as any other Alga. It might even be urged, 
that, as it has not only a wider geographical, but higher tide-mark distribution, in virtue of its greater power of resistance to extremes of temperature and wave-action, and is moreover perennial and capable of reproducing its like, Aglaozonia has even a better claim to be regarded as the most important of the two forms, and therefore more entitled to be regarded as the phylogenetic and theoretical gametophyte than the delicate, sexual Cutleria-shoot itself. To this view, however, there are serious morphological objections. In comparing the development of the two stages, it becomes evident that not only is there no special evidence of alternation which could be included under a theoretical alternation of generations, but that even the polymorphism is less evident than at first sight appears.

It is important to note that this polymorphy originates only in the embryonic history, leading to the formation of the embryos designated the Foot-Embryo and the Protonematoid Embryo respectively; and it is in this that its importance lies. Thus, as far as present data go, the dorsiventral Aglaozonia cannot recreate the erect plant vegetatively, nor can the adult Cutleria reproduce from the base of its main axis, clothed with rhizoids to form a secondary holdfast, the dorsiventral basal lobes; although a longitudinal section of the attachment-disc shows that at the extreme base it never gets beyond the simple segmentation of the foot (Fig. IO).

While the protonematoid embryo is clearly on the way to a true Cutleria-form, it is the foot-embryo which is aberrant in development, in that it presents an anomalous cessation of terminal growth at an early period; and thus the cause of polymorphy may possibly be sought in the solution of the problem as to what induces this arrest of a free-growing axis: that is to say,-Have we to do with the influence of environment on the germinating spore itself, or does it act upon the parent organism? Now, in comparing the April cultures of Aglaozonia with the September cultures of Cutleria, at Plymouth, it is difficult to see what 
marked differences of light or food-supply there can be at the two equinoxes. Thus, the two stages of germination were carried out in similar vessels, in the same window, at a laboratory temperature varying from $\mathrm{I} 2^{\circ}-20^{\circ}$, although the average was nearer $14^{\circ}$ for the spring and $18^{\circ}$ for autumn, and in similar water, in which, as it was not changed, similar gas-conditions must have obtained. Apparently the only factor which varied was that the Aglaozonia-plants had been resting throughout the winter at a temperature of $8^{\circ}-9^{\circ}$, and were in April reproducing on the spring rise to $12^{\circ}$, while the Cutleria-plants were vegetating and reproducing throughout July and August at I $8^{\circ}$. But although they continued to discharge oospheres on into the autumn at $14^{\circ}$, and possibly at less than $12^{\circ}$ in November, the parthenogenetic oospheres all gave true foot-embryos, without exception. As far as present data go, therefore, it would appear that inherited characters may play a certain part; but it has not yet been established that heredity has attained such a degree of importance in the life-history that any alternation is inevitable, much less sexually beneficial. Summing up these data, it remains shown that:-

I. Cutleria oospheres, whether fertilized in the Mediterranean (Falkenberg), presumably or actually parthenogenetic in the autumn in the English Channel, developed a foot-embryo, which resulted in definite Aglaozoniathallus and nothing beyond.

2. Aglaozonia zoospores produced a recognizable Cutleriaform, presenting all the essential characters of a Cutleriathallus with the exception of the fasciation of the branches (protonematoid embryo $=C$. multifida var. confervoides Kuckuck), - and under adverse conditions (since the plants died) producing antheridia in great numbers ; but also true Aglaozonia-discs.

3. Cutleria oospheres, germinated parthenogenetically by Thuret, under conditions not described, gave a true protonematoid embryo, which if it had lived would have undoubtedly given a Cutleria plant. 
And added to these, that:-

4. Janczewski, at Antibes in $18{ }^{8} 3$, germinated a true footembryo from fertilized oospores of $C$. adspersa, and this in subsequent development became a dorsiventral structure, closely comparable with many of the Plymouth embryos (Fig. I6). (A special point of interest attaches to Janczewski's cultures, since in them the arrest of terminal growth which forms the special characteristic of the foot-embryo is not complete ; the young foot-stages being figured as bearing a terminal filament with an intercalary zone of growth.)

5. Reinke, at Naples in 1876 , obtained protonematoid embryos, identical with Thuret's Cutleria-embryo, from both zoospores and fertilized oospores of Zanardinia collaris. (These stages, which were the most advanced obtained by Reinke for members of the Cutleriaceae, were also distinguished by presenting no trace of the tissue-fusion necessary to form the true adult thallus. They further differ from the Plymouth cultures very considerably in their rate of growth; a definite protonematoid embryo being only obtained by Reinke in three months, while one month at Plymouth gave the furthest vegetative stage observed. Nor was any trace whatever noticed of the peculiar phenomenon, suggested to be pathological, which Reinke describes and figures under the name of 'secondary spores,' in the germination of Zanardinia, Cutleria, and Aglaozonia).

6. Reinke also found the protonematoid embryo of Zanardinia growing in its natural habitat, and, as already indicated, the protonematoid embryo of $C$. multifida has been described as reproducing naturally at Heligoland (Kuckuck). 


\section{The Relation of Cutleria to Physical ENVIRONMENT.}

\section{Means of Dispersal.}

From evidence derived from floating bottles, it is clear that anything that will float will be carried indefinitely along the lines of currents and prevailing winds.

When it is borne in mind that the spores of Cutleria and Aglaozonia will germinate freely on the surface and float for at least the first month of their existence, and that the film of germinating spores may be at least equal in area to the plant producing them, it is clear that these plants must have practically unlimited powers of dispersal, and that their presence or absence at any given spot must be solely determined by the conditions of external environment.

\section{Relation to Temperature.}

Of the factors of external environment which influence the growth of marine Algae, temperature, light-intensity, the transparency of the water and velocity of current, the firstmentioned is the one most easily measured; and beyond small daily and local variations on the grand annual curve this is so remarkably constant that it is probable that the sensitiveness of marine vegetation to temperature will be found to lie within far narrower limits than in the case of subaerial vegetation. Thus, although seasonal changes are strongly marked, the extreme annual range which at Naples is $20^{\circ}$, is only $12^{\circ}$ at Plymouth, less than $8^{\circ}$ at Shetland, and as little as $6^{\circ}$ at points along the east coast of Scotland (Isle of May). The maximum temperature is found at the end of August, the minimum in February; the sea thus undergoing a steady and rapid rise in early summer, and a rapid fall in late autumn. The former is accompanied by a great amount of light-supply during the summer solstice, the latter by a great diminution in light-intensity towards 


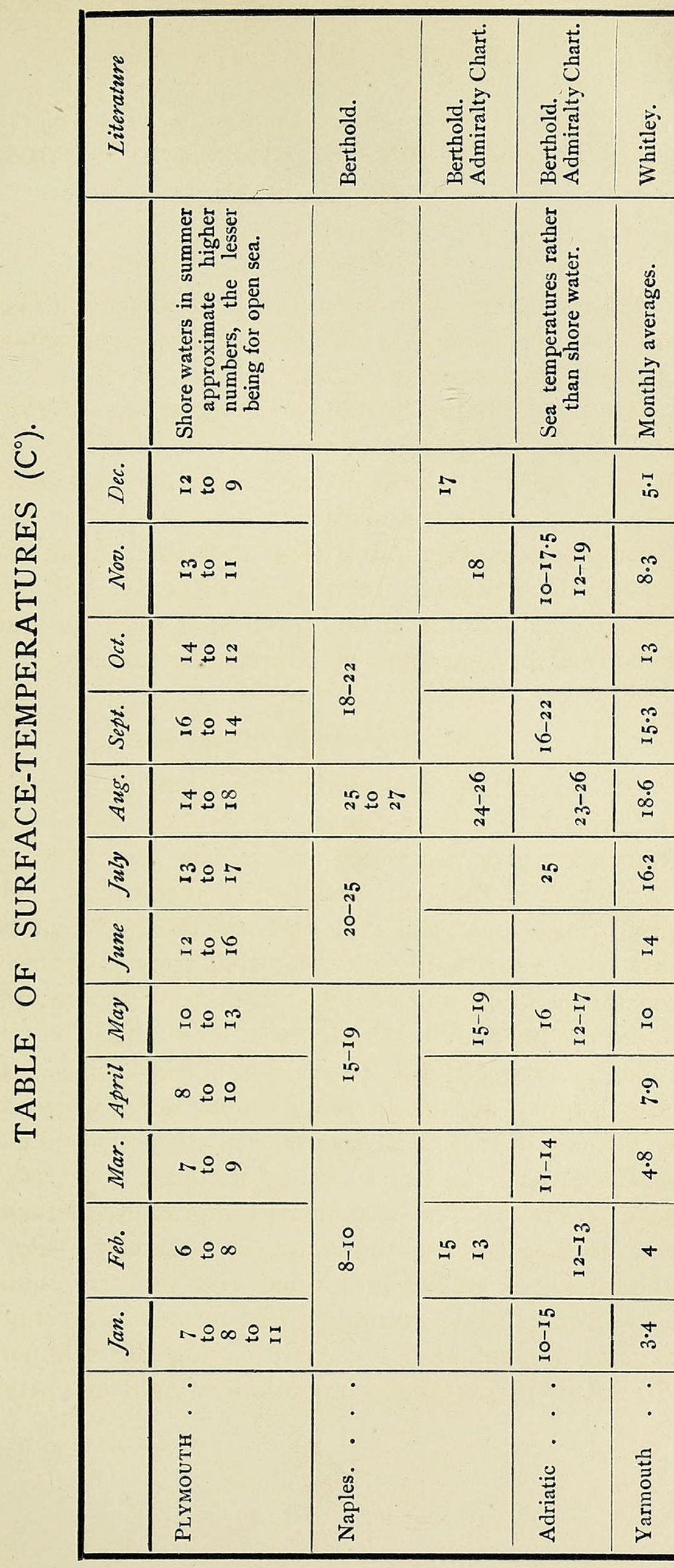



TABLE OF SURFACE-TEMPERATURES $\left(\mathrm{C}^{\circ}\right)$.

\begin{tabular}{|c|c|c|c|c|c|c|c|c|c|c|c|c|c|c|}
\hline & Jan. & Feb. & Mar. & April & May & June & July & Aug. & Sept. & Oct. & Nov. & Dec. & & Literature \\
\hline Plymouth . . & $\begin{array}{l}7 \\
\text { to } \\
8 \\
\text { to } \\
\text { II }\end{array}$ & $\begin{array}{c}6 \\
\text { to } \\
8\end{array}$ & $\begin{array}{l}7 \\
\text { to } \\
9\end{array}$ & $\begin{array}{l}8 \\
\text { to } \\
10\end{array}$ & $\begin{array}{l}\text { Io } \\
\text { to } \\
13\end{array}$ & $\begin{array}{l}12 \\
\text { to } \\
16\end{array}$ & $\begin{array}{l}13 \\
\text { to } \\
\text { I }\end{array}$ & $\begin{array}{l}\text { I4 } \\
\text { to } \\
\text { I } 8\end{array}$ & $\begin{array}{l}16 \\
\text { to } \\
14\end{array}$ & $\begin{array}{l}14 \\
\text { to } \\
\text { I2 }\end{array}$ & $\begin{array}{l}\text { I3 } \\
\text { to } \\
\text { II }\end{array}$ & $\begin{array}{c}\text { I } 2 \\
\text { to } \\
9\end{array}$ & $\begin{array}{l}\text { Shore waters in summer } \\
\text { approximate higher } \\
\text { numbers, the lesser } \\
\text { being for open sea. }\end{array}$ & \\
\hline \multirow[t]{2}{*}{ Naples. . . . } & \multicolumn{3}{|c|}{$8-10$} & \multicolumn{2}{|c|}{$15^{-19}$} & \multicolumn{2}{|c|}{$20-25$} & $\begin{array}{l}25 \\
\text { to } \\
27\end{array}$ & \multicolumn{2}{|c|}{ I8-22 } & & & & Berthold. \\
\hline & & $\begin{array}{l}\text { I5 } \\
\text { I3 }\end{array}$ & & & $15^{-19}$ & & & $24-26$ & & & I8 & 17 & & $\begin{array}{l}\text { Berthold. } \\
\text { Admiralty Chart. }\end{array}$ \\
\hline Adriatic . . . & IO-I 5 & I 2-13 & II - I 4 & & $\begin{array}{c}16 \\
12-17\end{array}$ & & 25 & $23-26$ & $16-22$ & & $\begin{array}{c}10-17 \cdot 5 \\
12-19\end{array}$ & & $\begin{array}{l}\text { Sea temperatures rather } \\
\text { than shore water. }\end{array}$ & $\begin{array}{l}\text { Berthold. } \\
\text { Admiralty Chart. }\end{array}$ \\
\hline Yarmouth . . & $3 \cdot 4$ & 4 & $4 \cdot 8$ & $7 \cdot 9$ & Io & 14 & 16.2 & 18.6 & ${ }^{1} 5 \cdot 3$ & I3 & $8 \cdot 3$ & $5 \cdot 1$ & Monthly averages. & Whitley. \\
\hline Bell Rock · & $4 \cdot 8$ & $4 \cdot 7$ & $4 \cdot 8$ & $5 \cdot 9$ & $8 \cdot I$ & 10.6 & $12 \cdot 4$ & I 3.3 & 12.6 & II $\cdot 2$ & $8 \cdot 4$ & $6 \cdot 5$ & Surface. & $\begin{array}{l}\text { Fishery Board for } \\
\text { Scotland, } 1895 .\end{array}$ \\
\hline Abertay ... & $4 \cdot 7$ & $4 \cdot 8$ & $4 \cdot 8$ & $6 \cdot 4$ & $8 \cdot 4$ & 10.8 & 12.8 & $13 \cdot 6$ & $12 \cdot 7$ & 10.7 & $7 \cdot 6$ & $6 \cdot 2$ & Three fathoms. & Ditto. \\
\hline Heligoland . . & $3 \cdot 7$ & $2 \cdot 7$ & $3 \cdot 1$ & $5 \cdot 2$ & 8.5 & 12.5 & ${ }_{1} 5 \cdot 6$ & 16.8 & I6.I & I3.I & $9 \cdot 3$ & $6 \cdot 2$ & Monthly averages. & Karsten. \\
\hline \multirow{2}{*}{ Kiel . . . . } & 1.8 & $1 \cdot 5$ & 2.5 & $6 \cdot I$ & $10 \cdot 7$ & ${ }^{1} 5.8$ & I 8 & 18 & ${ }^{1} 5 \cdot 8$ & II $\cdot 9$ & $7 \cdot 3$ & $3 \cdot 7$ & Surface. & \multirow{2}{*}{ Karsten. } \\
\hline & $2 \cdot 97$ & $2 \cdot 55$ & 3.08 & $5 \cdot 3$ & 8.6 & I 2.8 & ${ }^{1} 5 \cdot 2$ & I6.I & I $5 \cdot 4$ & $12 \cdot 4$ & $7 \cdot 9$ & $4 \cdot 2$ & Five fathoms. & \\
\hline Orkney . . . & 7 & 6 & 7 & $5-7$ & $8-9$ & $9^{-1 I}$ & $11-12$ & $\mathrm{I} 2-\mathrm{I} 3$ & I 2-I 4 & II & 11 & 9 & & $\begin{array}{l}\text { Whitley and Ad- } \\
\text { miralty Chart. }\end{array}$ \\
\hline Shetland . . . & 6 & $4-7$ & 5 & $5-7$ & $8-9$ & $9^{-12}$ & II-I3 & II -13 & II-I 2 & $8-$ II & $8-9$ & $6-8$ & & $\begin{array}{l}\text { Whitley and Ad- } \\
\text { miralty Chart. }\end{array}$ \\
\hline Skagerack . . & $\begin{array}{c}5 \\
\text { to } \\
7\end{array}$ & $\begin{array}{c}1 \\
\text { to } \\
4\end{array}$ & $\begin{array}{c}\circ \\
\text { to } \\
3\end{array}$ & $\begin{array}{c}4 \\
\text { to } \\
5\end{array}$ & $\begin{array}{c}6 \\
\text { to } \\
8\end{array}$ & $\begin{array}{l}10 \\
\text { to } \\
\text { I4 }\end{array}$ & $\begin{array}{l}15 \\
\text { to } \\
17\end{array}$ & ${ }^{\prime} 5$ & & $\begin{array}{l}\text { II } \\
\text { to } \\
\text { I3 }\end{array}$ & $\begin{array}{l}9 \\
\text { to } \\
10\end{array}$ & $\begin{array}{c}9 \\
\text { to } \\
6\end{array}$ & Open water. & Pettersson. \\
\hline \multirow[t]{2}{*}{ Christiania Fjord. } & & $2-I$ & & & & & 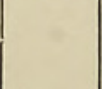 & I & & 12 & $5-7$ & & $\begin{array}{l}\text { Cold winter (Baltic } \\
\text { water). }\end{array}$ & \multirow{2}{*}{ Hjort. } \\
\hline & & $4-5$ & & & & & & & & II & $8-11$ & & $\begin{array}{l}\text { Warm winter (North Sea } \\
\text { water). }\end{array}$ & \\
\hline $\begin{array}{l}\text { Hardanger Fjord. } \\
\text { (Bergen) }\end{array}$ & & $\frac{3 \text { (cold) }}{6 \text { (warm) }}$ & 4 & & & & & I5 & & $\begin{array}{c}\text { II } \\
\text { to } \\
9\end{array}$ & $\begin{array}{l}8 \\
\text { to } \\
10\end{array}$ & & & $\begin{array}{l}\text { Hjort and Nor- } \\
\text { weg. N. At- } \\
\text { lantic Exped. }\end{array}$ \\
\hline Vigten Fjord & & 4 & 2 & & & & & $\begin{array}{l}12 \\
\text { to } \\
13\end{array}$ & & & 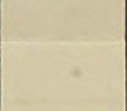 & & & Ditto. \\
\hline Lofoten Is. . . & & $\mathrm{I} \cdot 5$ & $I-3$ & & & & & $\begin{array}{l}\text { II } \\
\text { to } \\
\text { I } 2 \cdot 7\end{array}$ & & & 6 & & & $\begin{array}{l}\text { Ditto and Ad- } \\
\text { miralty Chart. }\end{array}$ \\
\hline
\end{tabular}




\begin{tabular}{|c|c|c|}
\hline 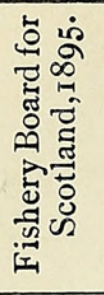 & 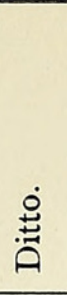 & 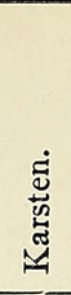 \\
\hline 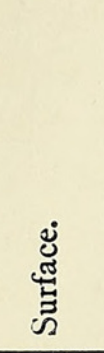 & 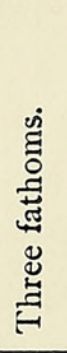 & 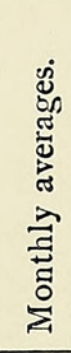 \\
\hline مُ & $\stackrel{\sim}{\dot{b}}$ & $\stackrel{\tilde{b}}{\dot{b}}$ \\
\hline$\stackrel{+}{\infty}$ & 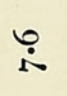 & $\ddot{a}$ \\
\hline 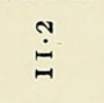 & $\stackrel{\hat{o}}{\dot{0}}$ & $\overrightarrow{\dot{r}}$ \\
\hline$\underset{\text { I }}{\stackrel{\text { I }}{ }}$ & $\stackrel{\vec{I}}{\stackrel{\sim}{\sim}}$ & $\underset{\sim}{\vec{b}}$ \\
\hline$\underset{\vec{n}}{\dot{m}}$ & 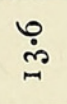 & $\stackrel{\infty}{\stackrel{\infty}{\mathscr{D}}}$ \\
\hline$\underset{\stackrel{+}{+}}{+}$ & $\stackrel{\infty}{\stackrel{\infty}{\sim}}$ & in \\
\hline 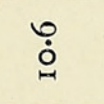 & $\stackrel{\infty}{\stackrel{\infty}{\circ}}$ & $\underset{\sim}{\stackrel{\text { s}}{ }}$ \\
\hline$\vec{\infty}$ & $\dot{\infty}^{+}$ & $\ddot{\infty}$ \\
\hline$\stackrel{9}{\text { is }}$ & $\dot{b}^{+}$ & in \\
\hline$\stackrel{\infty}{\dot{+}}$ & $\stackrel{\infty}{\dot{+}}$ & $\overrightarrow{\dot{r}}$ \\
\hline$\dot{\dot{\gamma}}$ & $\stackrel{\infty}{\dot{q}}$ & $\dot{\sim}$ \\
\hline$\stackrel{\infty}{\dot{+}}$ & $\dot{\dot{\sigma}}$ & $\hat{\text { is }}$ \\
\hline 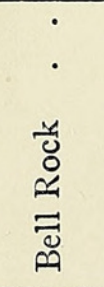 & $\begin{array}{l}\text { 离 } \\
\text { 岂 }\end{array}$ & 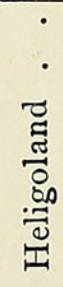 \\
\hline
\end{tabular}


the winter solstice. It is clear that in the case of free assimilating plants the light-intensity must be of supreme importance for food-supply and increase in bulk, and there can be no doubt that it is the abundance of light-supply on the ascending part of the temperature-curve which brings forward so rapidly the summer vegetation of the British seas; but on the other hand, these same two factors in the Bay of Naples appear to lead to the death of the greater number of the same plants, and the optimum vegetative period occurs there on the descending part of the temperature-curve with a diminishing light-supply.

Berthold $^{1}$, from his observations at Naples, came to the conclusion that optimum light-intensity and velocity of the current were the main factors, and temperature, although important, subsidiary to these. $\mathrm{He}$ bases his view chiefly on the manner in which the winter and spring annuals last on in deeper water or shaded situations; but it is clear that these conditions would also imply a lower degree of temperature by affording a protection from the direct heating effect of the sun's rays; while rapid movements of water, by carrying off the heated surface-layers, would produce a similar result. In the case of a plant which requires light for assimilation, it is difficult to isolate the heating effect from the light-intensity of the sun's rays; and as temperatures are easily recorded, it has been thought worth while to collect a few of the available data for different localities. As Cutleria grows in fairly shallow water, i.e. less than five fathoms, the temperatures of the surface-water will be sufficient; but it is to be noted that records of surface-temperatures along the shore vary much more than in the open sea, and those alone would be absolutely reliable which were taken on the spot where the plant was growing: for the influence of the land and winds on shallow water in enclosed areas leads to a source of error of possibly $2{ }^{\circ} \mathrm{C}$. from the average at Plymouth, while local variations are still greater in the Mediterranean. 
The observations made at Plymouth suggested that Aglaozonia vegetated at an optimum of $10^{\circ}-12^{\circ}$, but was perennial within the annual range of $6^{\circ}-18^{\circ}$; the zoospores germinated in the spring at $12^{\circ}$, and the optimum range of temperature for Cutleria was from $12^{\circ}-16^{\circ}$, this being accompanied by the great light-intensity of May and June. Under these conditions the thallus was mature and in full reproduction in four months, of which one month may be included in the protonematoid embryo stage. It died (in the Laboratory) at $20^{\circ}$, this temperature being reached at the end of August in shallow enclosed water, and also on the autumn fall to $13^{\circ}$. The autumn fall to $12^{\circ}$, although accompanied by great diminution in light in October and November, led to renewed growth of the Aglaozonia which perennated through the winter, growing slowly at its optimum temperature, but stopping if the light-supply was slight, as in dull weather in November and December. The same conditions were also fatal to the whole of the foot-embryos in all stages, which had not yet thrown out Aglaozonia expansions.

Complete data are not available for Naples, but the same annual period of maximum and minimum obtains, the range being from $8^{\circ}$ in January and March to $27^{\circ}$ in July and August. As before noted, temperatures to have more than an approximate value require to be taken where the Cutleria is growing, and as Berthold gives temperatures of $15^{\circ}$ and $17^{\circ}$ for February and December, it would seem that Cutleria lives in these waters under similar temperature-conditions to those which obtain in the Channel in summer; i.e. it commences growth on the autumn fall in December and matures in four months, completely disappearing in shallow water in April, as the temperature rises to near $20^{\circ}$. At the same time the Aglaozonia is perennial over the summer heat of $27^{\circ}$, or at any rate may exist in deeper and colder water. According to Berthold, a stunted growth of Cutleria also occurs in deep water in July and August to a certain extent, the temperature at the depth of growth, forty fathoms, being $14^{\circ}-17^{\circ}$, thus approximating the English temperature. This growth appears 
however not to have been investigated, the researches of Reinke and Falkenberg having been carried out on the winter-plants (cf. p. 109).

At Antibes the isothermals for surface-temperature very closely approximate those of Naples, and Cutleria has here the same annual period.

North Sea, Yarmouth, Heligoland. With a cold winter, late cold spring, and a rapid summer rise, the North Sea presents a variation of from $0^{\circ}$ to $\mathrm{I} 8^{\circ}$; the Heligoland curve averaging a degree lower on its rise than that of the western shore. The fall to zero is exceptional, and the mid-winter average for Heligoland is well over $2^{\circ}$, and possibly higher in sheltered localities. More complete data for the occurrence of Cutleria in the North Sea would be of great interest, as from the preceding it would appear that here the high degree of temperature necessary to form the mature plant did not obtain, as a rule, throughout a sufficient length of time; and this may possibly be the explanation of the fact that Cutleria has been found at Heligoland, but in recent years has only occurred in the protonematoid form as $C$. confervoides. Similarly, Cutleria is found at Yarmouth, but is not known to occur along the east coast until the sea at Orkney feels the influence of the warm Atlantic current, although Aglaozonia is often common (e.g. Berwick). It is therefore probable that we here reach the minimum heat-supply for the development of the typical Cutleria-thallus, owing to the fact that the optimum degree of temperature does not obtain over a sufficient period in the brightest months.

Similarly, Kiel has a still greater range, with a high summer temperature but very low mid-winter average, being below $3^{\circ}$ during the winter months, and often below zero. This appears to limit the Aglaozonia, and neither Aglaozonia nor Cutleria occur at Kiel or inside the Baltic.

Orkney and Shetland, owing to the presence of warm Atlantic water, show the smallest amount of annual variation, the characteristic feature being the warm winter; while the summer maximum is only $14^{\circ}$, the winter minimum is $4^{\circ}-5^{\circ}$. 
Orkney has a noticeably milder winter than that of Shetland, the February temperature being $6^{\circ}$. It is fully in agreement with previous statements that Aglaozonia should here perennate safely and Cutleria vegetate in the summer without reaching any great bulk; and it would appear that Pollexfen found all the Orkney specimens to be of the delicate 'penicillata' variety, which suggests but small amount of growth beyond the protonematoid condition.

Skagerack and Norwegian Coast. From the extensive researches of Pettersson and Hjort, it is known that the temperature of the Skagerack and West Norwegian shores varies from year to year according to the manner in which the summer-heated waters of the Baltic find an outlet into the Atlantic, giving rise in summer to a superficial Norwegian coast-current (the Baltic current) running close along the shore, and thus forming a strip of water from Christiania to Nordland warmer than that of the North Atlantic summer. The Skagerack average temperatures given by Pettersson, especially the higher ones which represent those of warmer seasons, compare very favourably with those of Yarmouth with the exception of the late spring-rise. Christiania Fjord is the warmest portion of the Norwegian seas, and the best Norwegian stations for Cutleria occur in this Fjord. In warm winters the surface-temperature does not fall below $5^{\circ}$, while the summer maximum is $17.2^{\circ}$; these numbers falling well within the suggested temperature-limits for Cutleria and Aglaozonia. On the other hand, as in the North Sea, it is clear that the critical temperatures are reached in passing up the West Norwegian coast, where Cutleria is found sparingly, Aglaozonia more commonly, extending as far as Nordland but not to Lofoten. Winter-temperatures along the coast again vary in different years according to the relative strength of the Baltic current, now cold at $2^{\circ}$ or less, and the open Atlantic at $6^{\circ}-7^{\circ}$. In warm winters the surface-temperature may be as high as $6^{\circ}$ at Hardanger Fjord and as much as $4^{\circ}$ at Vikten. On the other hand, the surface-layers lose heat in contact with the extreme low temperature of the air at 
Lofoten, and here the surface-temperature of the open sea falls to $1.5^{\circ}$ in February; this being again the Kiel average for the same month.

There is therefore a certain amount of evidence in favour of the view that temperature rather than light-intensity is the determining factor as far as the actual existence of these plants is concerned, and that while Cutleria vegetates at a mean of $16^{\circ}$, with a range of four degrees above and below, Aglaozonia prefers a mean of $10^{\circ}$, with a maximum considerably over $20^{\circ}$, and a minimum below $3^{\circ}$ : further, that a continuance of this low temperature limits the existence of both these plant-forms, in that it destroys the perennating thallus, both in the Baltic and along the Norwegian coast.

In order to test these data, observations were attempted at Plymouth in January, 1898, on perennating plants of Aglaozonia, both the adult thallus and also the young perennating plants of the first winter germinated the previous summer, large numbers of which were now from .5 to $2 \mathrm{~mm}$. long, and had been growing for months at an average temperature of $14^{\circ}$.

It is clear that in this case the action of a constant degree of temperature over a longer period of time than was available would be preferable, and the observations were not so successful as might have been wished owing to the difficulty of maintaining a constant temperature over a long period and at the same time maintaining general health-conditions by frequent change of water; and it is probable that the data derived from actual distribution are more likely to be correct than those derived from cultures in the laboratory so long as the difficulty of accurately imitating the natural environment remains. Thus, at $25^{\circ}-26^{\circ}$, the summer maximum for Naples, young perennating forms remained healthy for ten days, and although a few died, many were alive and well after sixteen days. At $27^{\circ}-29^{\circ}$, similarly, both young and old plants remained healthy after six days, and there seemed reason to believe that at temperatures below $30^{\circ}$ Aglaozonia might perennate successfully. 
At temperatures above $30^{\circ}$, on the other hand $\left(30^{\circ}-32^{\circ}\right)$, death occurred sooner or later; young plants dying in 2-4 days; older ones in $4^{-6}$ days, dying irregularly in patches. This is of interest as showing the unlikelihood of Cutleria crossing the Tropics where the maximum surface-temperature is above $30^{\circ}$.

Experiments at low temperatures were not conclusive, young plants remaining perfectly healthy after being surrounded by melting ice for six days.

\section{Theory of SEXUALity.}

The theory of the sexuality of the Phaeosporeae, which in point of fact still remains based on the classical researches of Reinke and Falkenberg on Cutleria, and those of Berthold on Ectocarpus siliculosus, has more recently been called in question by such accurate observers as Kuckuck and Sauvageau ${ }^{1}$, who have repeatedly failed in obtaining union of gametes in various species of Ectocarpus and allied genera. Thus Kuckuck maintains that Ectocarpus siliculosus is constantly parthenogenetic at Kiel, and it may be noted that Reinhardt has observed both copulation and direct germination of gametes in this species at Sevastopol; while Sauvageau in 1895 obtained direct germination in the case of the gametes of seven species of Ectocarpus and wholly negative results as regards a sexual process. No one, again, has ever observed sexual fusion in any of the plants of the Giffordia section of Ectocarpus which possess apparent antheridia, nor again with certainty in any of the Tilopterideae.

The facts in the case of Cutleria, however, appear to point to the narrow range of external conditions within which the sexual process can be effected: if these conditions do not obtain, the plant may fall back on parthenogenesis, which in 
northern waters is associated with a correlative diminution of the now useless male organs; so that, under extreme conditions, the admittedly asexual mode of reproduction alone remains on the perennating form. There can thus be little doubt that in the case of Giffordia and the Tilopterideae, purely morphological considerations may be a better guide to the theoretical degree of sexual specialization than the physiological observation of the act of fusion of the gametes ; and further, that until more complete physical data are forthcoming as to the exact conditions of the experiment, a single positive result must far outweigh many negative ones, and the evidence that the so-called plurilocular sporangia of the Phaeosporeae are not potentially gametangia remains inconclusive.

Nor, on the other hand, do the data for Cutleria point so much to an imperfectly differentiated or incipient sexuality, as to an actual and progressive loss of that function; and thus, by analogy, the conception that the primitive Ectocarpus-like ancestor of the Phaeosporeae was a sexual plant with isogamous gametes would be strengthened rather than undermined. At any rate it is clear that the actual data for any given plant can only be obtained by actual observations taken at different times of the year at different points of distribution.

\section{Phylogeny of Cutleria.}

All generalizations as to the phylogeny of existing Algae must, in the present state of our knowledge, be necessarily more or less founded on the very hypotheses the scientific botanist most desires to prove. At the same time the only proof of such hypotheses at present attainable consists in their complete agreement with ascertained facts; and thus so long as the tentative character of the proceeding is clearly borne in mind, it may become of interest to construct a phylogenetic scheme for the life-history of the genera Cutleria and 
$Z$ anardinia which will not only include the existing data, but may present some suggestions towards the solution of other algological problems.

The evolutionary specialization of the Cutleriaceae, with which we are here concerned, takes into account the vegetative structure only. A comparison of Cutleria multifida (including Aglaozonia reptans), Cutleria adspersa (and its suggested Aglaozonia chilosa), and Zanardinia collaris shows that in the structure of the reproductive organs the three types are identical. In both genera the asexual sporangia give rise to a few (6-10) large biciliated zoospores, and thus present an intermediate reduction-specialization as opposed, on the one hand, to the numerous spores from the unilocular sporangium of Ectocarpus siliculosus, \&c., and to the immotile monospore of the Tilopterideae on the other.

The antheridia show a slight advance on the primitive Ectocarpoid multilocular sporangium, in the more complete delimitation of the antherozoid-tissue, best seen in the skeleton framework remaining after emission of the antherozoids, but they have not attained such a high degree of specialization as that exhibited by the bottle-like antheridium of the Tilopterideae.

In the same manner, a further degree of reproductive concentration has, in correlation with the increase in bulk of the female gametes, reduced the segmentation of a multilocular gametangium to an oogonium of sixteen loculi, each producing a single oosphere; but this again is a lesser degree of reduction than that obtaining in the Tilopterideae with huge solitary oosphere.

Hence, in all three forms of reproductive organ, the Cutleriaceae offer a condition intermediate between the isogamous Ectocarpaceae and the completely heterogamous Tilopterideae; and they may, in view of the present vegetative condition of these two groups, be regarded as descended from a filamentous form which had attained the present comparatively high degree of sexual differentiation before passing beyond the branched filamentous condition in its vegetative structure. 
Again, in the Cutleriaceae, the presence of the filamentous stage is clearly marked :-

(1) The mature plant itself is but a fasciated structure of which the growing regions are still in the purely filamentous form; the assumption of growth by intercalary division, as opposed to the primary apical growth, being general throughout the whole group of the Phaeosporeae. The reproductive portions of the thallus are still wholly in the filamentous condition, and filaments bearing reproductive organs can be induced to grow and attach by rhizoids; while the attachment-disc is also a mere felted mass of rhizoids; the only portion of the thallus, in fact, which is not filamentous being the highly specialized assimilative region.

(2) The filamentous condition is characteristic of the embryogeny for a short period in the foot-embryo, but persisting to the adult condition in the protonematoid embryos which produced antheridia in the Plymouth cultures, as also in the female form C. confervoides found at Heligoland by Kuckuck.

In the evolution of the vegetative thallus from such a simple filamentous form, in which intercalary growth of the branches supersedes the original apical development, the first step in advance is marked by the regular segmentation of the cells of the main axes, by successive divisions by walls in planes at right angles to one another, leading to the more or less regular formation of a multicellular condition such as exists in many Phaeosporeae, e.g. simpler Sphacelarias, Myriotrichia, Desmotrichum. This massive type of thallus with purely radial symmetry is represented (I) by the foot-embryo, (2) by the basal region of the plant in the protonematoid embryo. In the same way this method of segmentation is ontogenetically repeated in the formation of sterile hair-like branches on the adult thallus.

As an example of such a plant-form in which the cortical cells send out basal lobes forming a dorsiventral disc around the point of attachment of the plant, Sphacelaria cirrhosa may be instanced; and it is clear that in the Sphacelariaceae differentiation has proceeded in two lines from such a simple 
form, giving (I) a further specialization of the shoot-system in Stypocaulon and Cladostephus; (2) a suppression of the shoot system, and reduction to the creeping dorsiventral disc alone in Battersia. Such a reduction to a dorsiventral creeping thallus is again in Algae, from a vegetative point of view, a distinctly down-grade specialization. The plant, by adopting a prostrate habit, exposes far less assimilatory surface to the action of light and free-flowing currents which bring both food and oxygen supply; on the other hand, it gains in the struggle to resist the tensions and tractions of wave motion, and will thus exist safely, not only throughout more stormy seasons, but farther up towards the tide-mark.

The relation of Cutleria to Aglaozonia, from a vegetative point of view, is simply that the two growth-forms representing the extreme cases of specialization of such types as Cladostephus and Battersia are here combined in a single species, and become fixed, one way or the other, at a very early stage. Thus it is interesting to note that the delicate Cutleria-thallus is confined to comparatively quiet waters and depths at least two fathoms below low-tide mark, and possesses a very slender point of attachment in relation to the bulk of the full-grown thallus; while Aglaozonia rises, from equal depths, to rocks even above the tide-mark in many localities (Sidmouth). Further, accompanying feeble powers of growth and nutrition, and possibly correlated with them, Aglaozonia possesses an increased power of withstanding extremes of temperature.

Beyond the 'massive' stage, the Cutleriaceae make one more advance, which forms the unique characteristic of the order. This consists in the fusions which take place between the axes produced from the independent filaments of the apex of the thallus, leading to a fasciated growth which further presents the complication of dorsiventrality. That this is not only the essential feature of the Cutleriacean type, but is the last and most recently acquired and therefore most mobile character, is suggested by the following considerations.

(I) The specific characters are essentially based on the 
characters of the fasciated shoot; variations in this point being still considerable, giving rise to growth-forms which have been regarded as varieties; those with a lesser degree of fasciation being extremely common, especially in localities where external conditions are unfavourable. (Orkney; cp. C.penicillata, Lamour ; C. penicillata, Kützing).

(2) It is now the only character left which has not been observed in cultures, and it would therefore appear to demand the most delicate adjustment of external assimilative conditions.

Considering the three types from the standard of attainment of this assimilative growth-form, it would appear that $C$. multifida, which covers the widest range of temperature in distribution, presents these specializations in a high degree in its sexual shoot, but maintains existence under conditions unfavourable to its development by reduction to a degenerate creeping Battersia-like form, which alone persists at the extreme northern limit of distribution.

C. adspersa, with a considerably narrower range of distribution, exhibits a thallus, meagre by comparison with C. multifida, but more dorsiventral. Its Aglaozonia-stage, suggested for $A$. chilosa by Falkenberg, has not been more definitely isolated ; but Janczewski showed that the foot-embryo passed directly into a dorsiventral disc on the approach of summer at Antibes.

Finally, in Zanardinia collaris the fasciated shoot, with extreme dorsiventral development, becomes itself prostrate, and by vegetating in the manner of an Aglaozonia-disc in the hot summer does away with the necessity for such a basal formation from the embryo; and thus, being itself homotypic and obtaining the perennating advantages of the procumbent growth-form, presents the paradox of becoming degenerate by carrying to extremes the last variation of the family.

During a portion of the time in which these observations have been made, the writer has occupied the Oxford University Table at the Laboratory of the Marine Biological Association at Plymouth ; and in acknowledging the goodwill and unfailing 
courtesy with which the resources of the Station have always been placed at his disposal by the Director, Mr. E. J. Allen, he would wish to draw the attention of English algologists to the facilities afforded by the geographical position of the Plymouth Laboratory for the study of our native Algae.

Grateful acknowledgments are also due to Mr. E. A. Batters for kind assistance on many out-of-the-way points not easily obtained from the literature.

Postscript.-Since writing the above, Dr. P. Mayer kindly informs me that sea-temperatures taken on different days at Naples during the months December, I 897, and January, I 898 , for localities in which Cutleria is known to occur, ranged between $13.5^{\circ}$ and $13.9^{\circ}$. This adds confirmation, therefore, to the data obtained at Plymouth, which tended to show that the young Cutleria-thallus vegetates normally between $12^{\circ}-14^{\circ}$.

\section{EXPLANATION OF FIGURES IN PLATES VII, VIII, AND IX.}

Illustrating Mr. Church's paper on Cutleria multifida.

PLATE VII.

All figures drawn with Zeiss D. Oc. 3, and slightly reduced in reproduction.

Fig. I. Germination of zoospores of Aglaozonia (2-3 days).

Fig. 2. Older stage (one week old).

Fig. 3. Protonematoid Cutleria producing antheridia (August).

Fig. 4. Aglaozonia-disc produced at the base of protonematoid Cutleria (August).

Fig. 5. Germination of zoospores of Aglaozonia (two weeks old). 


\section{Cutleria multifida (Grev.).}

\section{PLATE VIII.}

All figures drawn with Zeiss D. Oc. 3, and slightly reduced.

Figs. 6-9. Protonematoid Cutleria, three weeks old.

Fig. 9. Embryo with multicellular ' foot'-like base.

Fig. Io. Protonematoid Cutleria, four weeks old, with attachment disc.

Fig. I I. Parthenogenetic germination of oospheres of Cutleria.

Fig. I 2. Embryos, one week old.

Fig. 13. Embryos, becoming multicellular, two weeks old.

Fig. I4. Foot-embryos, three weeks old.

\section{PLATE IX.}

Figs. I 5-21, Zeiss D. Oc. 5 ; Figs. 22, 23, Zeiss D. Oc. I ; and all slightly reduced.

Fig. I5. Development of Aglaozonia-disc from a single superficial cell by successive $T$-shaped walls.

Fig. 16. Small foot-embryo, wholly growing into Aglaozonia form.

Fig. I7. Terminal development of disc.

Fig. I 8. Lateral development of disc.

Fig. 19. General case of basal development of Aglaozonia expansion.

Figs. 20, 2I. Three to four weeks old embryos, giving disc-growths at various points. 20, dorsal; $2 \mathrm{I}$, ventral surface.

Fig. 22. Older foot-embryo with basal disc.

Fig. 23. Older embryo with Aglaozonia expansion well developed (Nov.). 


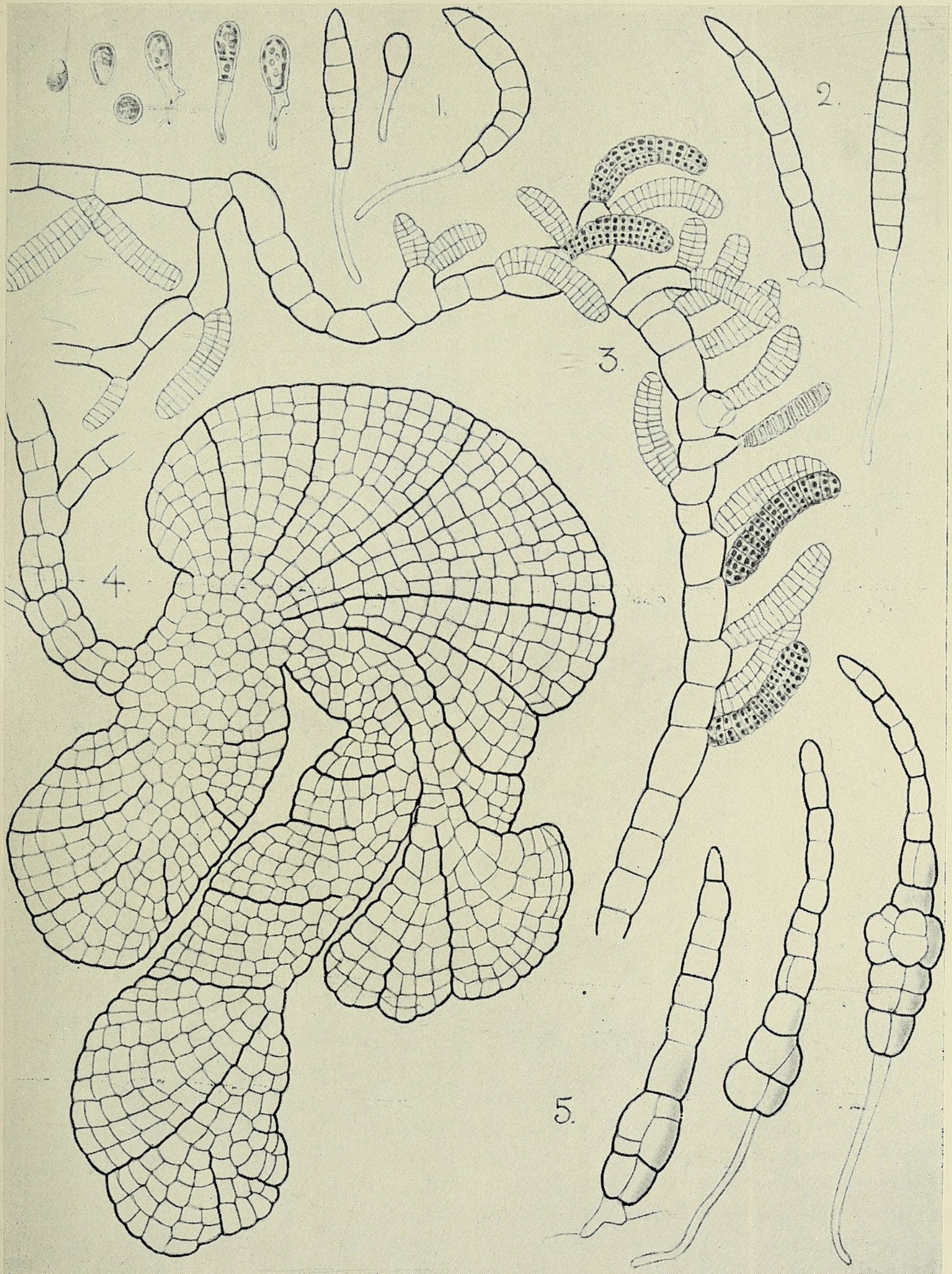

A.H. CHURCH. WEL. 97. 


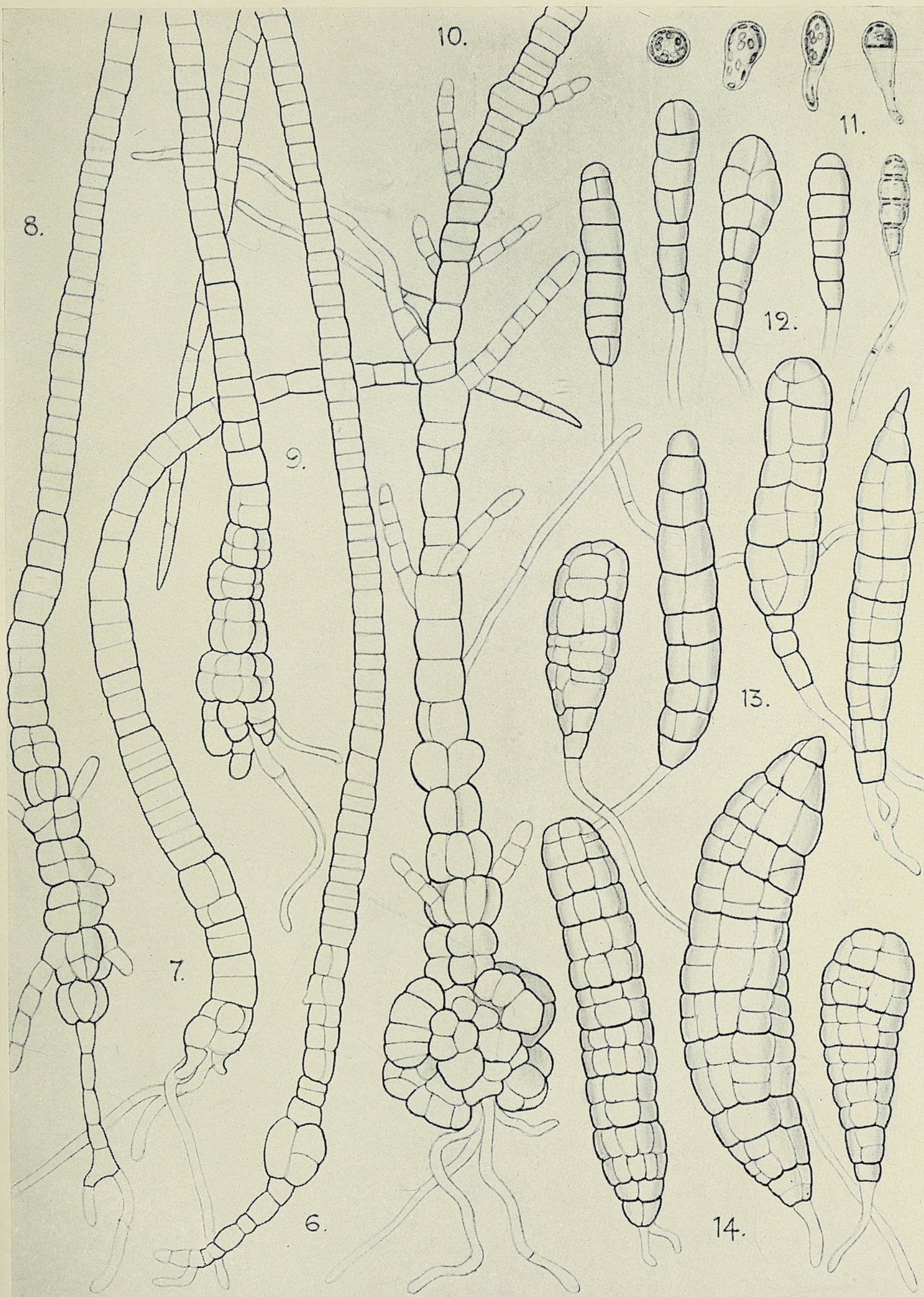

A.H.Church. Jelt/9r. 


\section{$2 \mathrm{BHL}$ Biodiversity Heritage Library}

Church, A. H. 1898. "The polymorphy of Cutleria multifida (Grev.)." Annals of botany 12, 75-109. https://doi.org/10.1093/oxfordjournals.aob.a088685.

View This Item Online: https://www.biodiversitylibrary.org/item/233102

DOI: https://doi.org/10.1093/oxfordjournals.aob.a088685

Permalink: https://www.biodiversitylibrary.org/partpdf/318493

\section{Holding Institution}

Smithsonian Libraries

\section{Sponsored by}

Biodiversity Heritage Library

\section{Copyright \& Reuse}

Copyright Status: Not in copyright. The BHL knows of no copyright restrictions on this item.

This document was created from content at the Biodiversity Heritage Library, the world's largest open access digital library for biodiversity literature and archives. Visit BHL at https://www.biodiversitylibrary.org. 